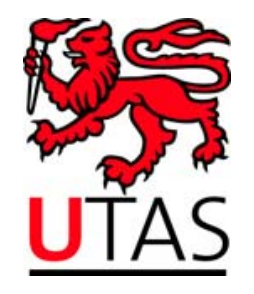

SCHOOL OF ECONOMICS AND FINANCE

Discussion Paper 2013-07

\title{
Chinese Resource Demand and the Natural Resource Supplier
}

Mardi Dungy, Renée Fry-McKibbin and Verity Linehan

ISSN 1443-8593

ISBN 978-1-86295-719-0 


\title{
Chinese Resource Demand and the Natural Resource Supplier*
}

\author{
Mardi Dungey \%, Renée Fry-McKibbin\% and Verity Linehan\% \\ ${ }^{\%}$ CAMA, The Australian National University \\ University of Tasmania
}

June, 2013

\begin{abstract}
This paper provides empirical evidence on the effects of Chinese resource demand on the resource rich natural resource supplier using the example of Australia. A structural VAR model is used to examine the effects of Chinese resource demand, commodity prices and foreign output on the macroeconomy with a formally specified mining and resources exports sector. The key findings of the paper are that shocks to Chinese demand and commodity prices result in a sustained increase in commodity prices and mining investment and a positive impact on the resources sector. However, these shocks eventually lead to lower real domestic output with factors of production moving out of the non-resources sectors and into the resources sector, resulting in a fall in non-resource sector output which is not fully offset by the rise in resources sector output. The results also indicate some market power by the natural resource supplier.
\end{abstract}

*The authors thank Michael Harris and Hilde Bjornland for helpful comments. Author contact details are mardi.dungey@utas.edu.au; renee.mckibbin@anu.edu.au. McKibbin acknowledges support from ARC Discovery Project DP0664024. 


\section{Introduction}

The sustained rapid industrialization and urbanization of emerging economies of the 1990s to the mid-2010s has driven unprecedented demand for natural resources (Roache, 2012). Much of this demand is driven by growth in China. Industrialization causes booms in demand for metals in particular (Humphreys, 2010), and by the end of the first decade of the 21st century China accounted for approximately two-thirds of world iron ore demand, around one-third of aluminum ore demand and more than 45 per cent of global demand for coal (Roberts and Rush, 2010). While China expanded domestic metals production during this period as exemplified by the rapid increase in Chinese steel production, demand for resources was unable to be satisfied domestically and imports from resource rich countries were a feature of this boom. Although there were considerable concerns about global overcapacity for steel production around the turn of the century, this has proven unfounded (Connolloy and Orsmond, 2011). There are potentially substantial spillover effects of rapid industrialization of this nature to other markets. This paper looks at the issue of the effects of an extensive and sustained resources boom transmitted to the macroeconomy of the source of natural resources using the example of China and Australia. Over the period in question, Australia experienced an externally driven resources boom that resulted in a surge in mining investment and output, with a significant part of this drive emanating from China (Plumb, Kent and Bishop, 2013; Battellino, 2010; Zhang and Zheng, 2008).

For the resource rich economy, externally driven booms have important policy implications. For example, there is a long history on the effects of the presence of Dutch Disease (see for examples Corden and Neary, 1982; Corden, 1984; Sachs and Warner, 1999; Gylfason et al. 1999; Stijins, 2005; Beine, Bos and Coulombe, 2012), Vespignani (2013) shows that Australian monetary policy is ineffective in altering conditions for the mining industry during resource booms, and the fiscal implications arising from large profits in the resources sector can be substantial. See the debate on the mineral resource rent tax in Australia (Mercer, 2011) and the role of soverign wealth funds in resource rich economies (Truman, 2011). To capture the impact of the resources boom on a resource rich small open economy and to analyze the surrounding issues,

the modelling framework developed in this paper interacts a foreign sector consisting of Chinese resource demand, world commodity prices and world output, with a domestic resource sector of mining investment, real exports and the exchange rate, and also with the macroeconomy. The questions addressed are: i) what are the effects of shocks from a rapidly growing emerging economy extracting resources from a developed natural 
resource rich economy on aggregate economic outcomes such as output growth, the interest rate, inflation and the exchange rate of the natural resource supplier; ii) how does the transmission of these shocks compare to general commodity price shocks once the China effects are abstracted from; iii) how does the transmission of these shocks compare to general foreign output shocks that are not dominated by resource demand; iv) how does the domestic resource export sector and the domestic mining sector react to the rapidly growing emerging economy under these circumstances; v) and how does mining investment and other economic activity in the natural resource economy feedback to affect the resource sector in the boom economy?

The Australian economy is a natural choice to examine the issues canvassed above. Australia's terms of trade rose significantly over the past decade, reaching a record high in September 2011 (Figure 1). Over this period, the price of exports increased substantially primarily due to Australian resource exporters receiving higher commodity prices as demand for Australian resources boomed (Figure 2). Most notably, increased demand from steel producers, especially in China, drove up the prices of iron ore and coal. Rayner and Bishop (2013) estimate that resource extraction alone accounted for 11.5 percent of Australian Gross Value Added in 2011/12. Due to higher global commodity prices and the associated rise in the terms of trade, the level of Australia's income was boosted, and resulted in a 'once-in-a-century boom in mining investment and the terms of trade' (Lowe, 2012); see also Figure 3. Revenue from mining increased at an average annual rate of around 15 percent in the first decade of the 21st century (Connolly and Orsmond, 2011); due not only to higher commodity prices, but also increasing output (Mudd, 2010).

The modelling framework is a structural vector autoregression (SVAR) model commonly used in empirical macroeconomics as a convenient data driven tool for quantifying the dynamic effects of shocks originating in different parts of an economic system on other variables. That is, it represents an empirically estimated system of dynamic interactions across the economy rather than a single equation approach such as earlier work on China's demand for Australian iron ore in Tcha and Wright (1999) or a theoretically motivated description of stylized facts as in Plumb, Kent and Bishop (2013). While SVAR models of Australia have previously considered the effects of shocks to the relative price of international commodities via either commodity price indices, or terms of trade variables, none have directly considered the growing impact of China's demand for resources on Australia (Dungey and Pagan, 2000; Berkelmans, 2005; Lawson and Rees, 2008; Liu, 2008; Jääskelä and Smith, 2011). This paper extends the model of Dungey and Pagan (2000) to include factors specific to the resources sector. While 
other studies include commodity prices, this study also includes a Chinese resource demand resources variable, resource exports and a mining investment indicator.

The key findings of the paper are that shocks to Chinese steel production and commodity prices result in a sustained increase in commodity prices and mining investment of around 40 years, and are likely to result in a positive impact on the resources sector in terms of resource exports and mining investment. However, in the longer term there is some evidence of Dutch Disease as these two shocks result in lower real domestic output after the first year, with factors of production moving out of the non-resources sectors and into the resources sector, resulting in a fall in non-resources sector output which is not fully offset by the rise in resources sector output. ${ }^{1}$ The results also indicate that large natural resource suppliers have some market power in the pricing in commodity markets. After six years, 10 - 13 per cent of the variablility of the Chinese steel production variable and the commodity price variable comes from shocks in Australian inflation. Finally, for resource exports, it is the booming sector in China and world demand rather than commodity prices and the exchange rate that are important in the longer term.

The paper proceeds as follows. Section 2 presents the empirical framework developed to analyze the questions above, outlines the data and sample as well as the modelling identification assumptions chosen. Section 3 presents results illustrating the effects of a resource boom on the resource rich economy. This section presents the model impulse response functions for shocks to Chinese resource demand, commodity prices and to foreign output, and is followed by analysis of the variance decompositions of the model focusing on the decompositions for the external sector and output in Australia. Some robustness to alternative definitions of the key variables in the model is also provided. Section 4 concludes.

\section{Empirical Framework}

An SVAR model describes the interaction between a set of variables, $X_{t}$, as

$$
B(L) X_{t}=\varepsilon_{t}
$$

where $B(L)$ is a $p^{t h}$ order matrix polynominal in the lag operator $L, B(L)=B_{0}-B_{1} L-$ $B_{2} L^{2}-\ldots-B_{p} L^{p} . B_{0}$ is a non-singular matrix normalized to have ones on the diagonal and summarizes the contemporaneous relationships between the variables in the model

\footnotetext{
${ }^{1}$ Although the model can obtain some insights on the presence of Dutch disease, our focus is not directly on sectoral adjustment.
} 
contained in the vector $X_{t}$. Here $X_{t}$ is a $n \times 1$ vector of endogenous macroeconomic variables. The $n \times 1$ vector $\varepsilon_{t}$ contains the serially uncorrelated structural shocks which are identified by placing parametric restrictions on $B_{0}$ and which has the properties $E \varepsilon_{t} \varepsilon_{t}^{\prime}=D$ and $E \varepsilon_{t} \varepsilon_{t+s}=0$, for all $s \neq 0$. D is a diagonal matrix containing the variances of the structural disturbances.

The reduced form VAR representation of the structural model is

$$
A(L) X_{t}=u_{t}
$$

where $A(L)$ is a matrix polynomial in the lag operator $L$, and where $A(L)=B_{0}^{-1} B(L)=$ $I-A_{1} L-A_{2} L^{2}-\ldots-A_{p} L^{p}$. The vector of serially uncorrelated reduced form disturbances is $u_{t}$ with mean zero and variance covariance matrix $E u_{t} u_{t}^{\prime}=\Sigma, E u_{t} u_{t+s}^{\prime}=0$, for all $s \neq 0$. The structural disturbances and the reduced form residuals are related by $u_{t}=B_{0} \varepsilon_{t}$.

There are five methods for recovering the parameters in the structural form equations from the estimated parameters in the reduced form equation (Fry and Pagan, 2011). This paper places restrictions informed by economic theory on the contemporaneous structural parameters. The results are analyzed in Section 3 by calculating the impulse response functions of the structural shocks on the system and through variance decompositions of the key variables in the model from the parameters of the SVAR. See Hamilton (1994) for further details on their calculation.

Estimation of the model takes place in EViews following Amisano and Giannini (1997). The method estimates a form of the SVAR known as an AB SVAR with $A u_{t}=B \varepsilon_{t}$. The $A$ matrix contains the contemporaneous parameters and the $B$ matrix controls the variance-covariance matrix of the structural innovations. The structural innovations $\varepsilon_{t}$ are assumed to be orthonormal, such that the covariance matrix is an identity matrix $E \varepsilon_{t} \varepsilon_{t}^{\prime}=D=I$. The assumption of orthonormal innovations $\varepsilon_{t}$ imposes

identifying restrictions on $A$ and $B: A \Sigma A^{\prime}=B B^{\prime}$ which requires at least $\left(k^{2}+k\right) / 2$ restrictions to be imposed on the parameters of the $A$ and $B$ matrices.

\subsection{The data and sample}

There are nine variables included in $X_{t}$. The external sector variables include a Chinese resource demand variable $\left(c s p_{t}\right)$, real commodity prices $\left(p c_{t}\right)$, foreign output $\left(y w_{t}\right)$ and the real value of Australian resource exports $\left(r e s x_{t}\right)$. The domestic variables include a mining sector variable $\left(\right.$ mininv $\left._{t}\right)$, domestic output $\left(y d_{t}\right)$, the inflation rate $\left(p d_{t}\right)$, the cash rate $\left(r d_{t}\right)$ and the real exchange rate $\left(q_{t}\right)$. All data are quarterly. Appendix A contains a full description of the data and their sources. 
A Chinese resource demand variable $\left(c s p_{t}\right)$ accounts for China's demand for inputs into steel production (see Tcha and Wright, 1999; Feng, 1994; and Zhang and Zheng, 2008 for work on China's demand for iron ore from Australia in particular). Three different options for this variable are considered. These are Chinese steel production, Chinese manufacturing exports and the Chinese industrial production index. Chinese steel production is the most directly related variable for Chinese resource demand, so this is the variable used in the baseline specification. The alternatives, are supported by evidence from Roberts and Rush (2010) that China's manufacturing exports are a significant driver of its demand for Australia's resource commodities in recent decades, and Chinese industrial production as a more general measure of demand in the Chinese economy. ${ }^{2}$

The international relative price variable used in this paper is the real commodity price index $\left(p c_{t}\right)$ and given the focus on the effects of external resource demand on the resource rich economy of Australia, the Reserve Bank of Australia (RBA) Index of Commodity Prices in US dollars is chosen. This index includes prices of twenty of Australia's key commodities which account for 85 per cent of primary commodity earnings (RBA 2009). Berkelmans (2005) and Lawson and Rees (2008) also include real commodity prices in their Australian SVAR studies, while Dungey and Pagan (2000; 2009) use the terms of trade, Brischetto and Voss (1999) include world oil prices and Jääskelä and Smith (2011) include import price inflation and export price inflation. This paper uses commodity prices rather than the terms of trade to specifically understand the interaction of commodity prices with other key macroeconomic variables (see also Sims 1992; Berkelmans 2005; Lawson and Rees, 2008).

The foreign output variable $\left(y w_{t}\right)$ is measured as the export-weighted real GDP of Australia's major trading partners, which includes China. This is the same measure as used in Jääskelä and Smith (2011).

The real value of Australian resource commodities exports $\left(r e s x_{t}\right)$ is the fourth external sector variable in the model. Higher commodity prices have had a significant impact on the value of Australian resource exports over the past decade, which has flowed through to higher income, investment, tax revenue and employment in the resources sector (Connolly and Orsmond, 2011). The definition of resources exports follows the ABARES (2011) definition of mineral exports, which is metal ores and coke and coal, and does not include oil which is relatively less important for Australia.

A mining indicator $\left(\right.$ mininv $\left._{t}\right)$ is included to examine the effect of the external factors on the Australian resources sector. Mining gross value added and mining investment

\footnotetext{
${ }^{2}$ Chinese GDP growth is taken into account in the foreign output variable.
} 
are considered, with mining investment chosen for the baseline model.

The Australian macroeconomic variables are GDP $\left(y d_{t}\right)$, inflation $\left(p d_{t}\right)$, an interest rate $\left(r d_{t}\right)$ and the exchange rate $\left(q_{t}\right)$. We use inflation rather than the price level, as the objective of monetary policy in Australia is the inflation target (Dungey and Pagan, 2000 and Berkelmans, 2005, and for an alternative Brischetto and Voss, 1999). The overnight cash rate is chosen as the interest rate variable as it has been the main monetary policy instrument since the floating of the Australian dollar in December 1983. The exchange rate is represented by the real trade-weighted index calculated by the Reserve Bank of Australia. These variable choices are largely consistent with Brischetto and Voss (1999), Dungey and Pagan (2000, 2009), Berkelmans (2005), Lawson and Rees (2008) and Jääskelä and Smith (2011)

The model is estimated using quarterly data from March 1988 to June 2011 for $T=94$ observations. Many Australian SVAR studies begin in the post-float period, usually the fourth quarter of 1983 or the first quarter of 1984, however the start date of this sample is later due to the mining investment data series beginning in 1988 . The sample end date is consistent with Jääskelä and Smith (2011). As in Dungey and Pagan (2000) and Dungey and Fry (2009), the non-stationary variables are all linearly detrended and expressed in log form, with the exception of the inflation rate which is in percentage point terms. ${ }^{3}$

The lag length specification tests suggest that either one (Schwartz Bayesian Information Criterion), two (Hannan-Quinn information criterion) or seven (Akaike Information Criteria, Likelihood Ratio) lags should be included. Including too many lags risks over-parameterising the model (Hamilton 1994), so a lag length of $p=2$ is chosen. Dungey and Pagan (2000), Berkelmans (2005) and Lawson and Rees (2008) use three lags while Brischetto and Voss (1999) use six lags.

\footnotetext{
${ }^{3}$ Statistical testing shows that the SVAR has stable roots.
} 


\subsection{Identification}

Structural shocks in the SVAR are identified by placing restrictions on the contemporaneous impact matrix

$$
B_{0} X_{t}=\left[\begin{array}{ccccccccc}
1 & 0 & 0 & 0 & 0 & 0 & 0 & 0 & 0 \\
b_{21} & 1 & 0 & 0 & 0 & 0 & 0 & 0 & 0 \\
b_{31} & b_{32} & 1 & 0 & 0 & 0 & 0 & 0 & 0 \\
b_{41} & b_{42} & b_{43} & 1 & 0 & 0 & 0 & 0 & 0 \\
b_{51} & b_{52} & b_{53} & b_{54} & 1 & 0 & 0 & 0 & 0 \\
b_{61} & b_{62} & b_{63} & b_{64} & b_{65} & 1 & 0 & 0 & 0 \\
0 & b_{72} & 0 & 0 & b_{75} & b_{76} & 1 & 0 & 0 \\
0 & b_{82} & 0 & 0 & b_{85} & b_{86} & b_{87} & 1 & 0 \\
b_{91} & b_{92} & b_{93} & b_{94} & b_{95} & b_{96} & b_{97} & b_{98} & 1
\end{array}\right]\left[\begin{array}{c}
c s p_{t} \\
p c_{t} \\
y w_{t} \\
r e s x_{t} \\
\text { mininv }_{t} \\
y d_{t} \\
p d_{t} \\
r d_{t} \\
q_{t}
\end{array}\right]
$$

The contemporaneous matrix $B_{0}$ is essentially lower triangular, with the assumption that domestic variables do not affect foreign variables contemporaneously as Australia is a small open economy. Australia is able to affect the external sector with a lag given the possibility of commodity exporting countries having some degree of market power in the resources sector by being able to pass on domestic cost increases (Clements and Fry, 2008; Dornbusch, 1987; Sjaastad, 1998a,b).

The Chinese resource demand variable is ordered first with the expectation that this resources demand will have flow on effects to commodity prices and foreign output. As in Brischetto and Voss (1999) and Berkelmans (2005), commodity prices are ordered before the foreign output variable. The foreign variables affect domestic variables contemporaneously, with the exception of the interest rate and inflation which is only affected through the lag structure. As in Berkelmans (2005) and Lawson and Rees (2008) domestic monetary policy and inflation will not react immediately to shocks to foreign output, and this is extended to the Chinese demand variable and Australian resource exports. Inflation responds immediately to domestic output, which is common in Australian SVAR studies (Brischetto and Voss, 1999; Dungey and Pagan, 2000). The exchange rate is assumed to respond contemporaneously to all variables, as is common in SVAR studies.

\section{Effects of a Boom on a Resource Rich Economy}

This section analyses the impulse responses of one standard deviation innovations to the booming sector of Chinese resource demand $\left(c s p_{t}\right)$, commodity prices $\left(p c_{t}\right)$ and to foreign output $\left(y w_{t}\right)$. These impulse responses illustrate the dynamic effects of structural shocks on each variable in the model, providing a useful insight into the 
relationships between variables. Asymptotic standard errors of two standard deviations for the impulse responses are illustrated in the figures. The impulse responses functions are presented over 24 quarters or 6 years. ${ }^{4}$

\subsection{Shock to Chinese resource demand}

The shock to Chinese steel production $\left(c s p_{t}\right)$ results in higher steel production in China for more than six years (Figure 4). In response to this shock, despite the increase in global supply, commodity prices received by Australian resource exporters rise reflecting that it is demand driving the booming Chinese economy. The rise in commodity prices peaks five quarters after the shock at 3.8 per cent above the baseline. They remain above the baseline for quite some time, and at the end of the sixth year after the shock are still 2.6 per cent higher than their original level. They eventually return to baseline after about 40 years, supporting analysis that suggests the effects of higher demand from China may be very long-lived indeed; see for example Humphreys (2010).

The Chinese resources demand shock initially has an expansionary effect on the Australian economy. Although mining investment initially falls, possibly due to the existence of a delay between the onset of higher commodity prices and the ramp up of mining investment noted in Plumb, Kent and Bishop (2013), mining investment remains above the baseline from the second quarter onwards, stabilizing at approximately 3.0 per cent above the baseline, six quarters after the shock. Domestic output increases as a result of the shock, remaining above its baseline level for the first six quarters. It then drops off in response to the tighter monetary policy that is invoked as the economy expands and to the movement of factors of production out of the non resources sector and into the expanding resources sector, reminiscent of Dutch Disease. Although there is higher external resource demand, the combined increase in commodity prices and appreciation of the exchange rate actually results in a fall in the real value of Australian resource exports, although this is not inconsistent with export volume increasing (Plumb, Kent and Bishop, 2013). During the boom period the large increase in the real exchange rate affected the non-tradeable sectors particularly in manufacturing, construction and accommodation (Connolly and Orsmond, 2011) in particular.

Higher domestic activity and commodity prices place inflationary pressure on consumer prices. Over the longer horizon, with Chinese steel production and foreign output trending up to baseline levels, and with domestic output below its baseline

\footnotetext{
${ }^{4}$ Note that the impulses converge over a longer time horizon.
} 
level, the inflation rate falls back to its baseline level. It should be noted that the raw data shows that inflation in Australia remained within the target band during the boom period (Plumb, Kent and Bishop, 2013). The interest rate responds to higher commodity prices, domestic activity and inflation, by increasing sharply in the first four quarters after the shock. However, the slowdown in domestic activity and foreign output pull the interest rate back to its baseline level five years after the shock. The exchange rate appreciates by 1.8 per cent in the first two periods after the shock, and despite coming off this peak remains around one per cent above the baseline for quite some time. The path of the exchange rate is consistent with the trends in the booming sector.

\subsection{Shock to commodity prices}

The one standard deviation shock to commodity prices represents an increase of 3.4 per cent, peaking two quarters after the shock at 4.7 per cent above the baseline (Figure 5). Commodity prices stabilize to remain approximately 4 per cent above the baseline for a substantial period of time before converging to their initial values around 18 years later. Consistent with Jääskelä and Smith (2011), and as expected if the commodity price shock is in fact a negative 'commodity supply' shock, commodity prices rise, increasing the price of goods that use those commodities as an input, while foreign output falls.

There is an instantaneous increase in the real value of resource exports as a result of higher commodity prices. However, resource exports fall below the baseline level in the second quarter as Chinese steel production and foreign output fall, though resource exports do begin to recover in the sixth year after the shock as Chinese steel production and foreign output pick up again. Mining investment responds positively to the rise in commodity prices, increasing by 1.4 per cent contemporaneously, and remains above the baseline level over the impulse horizon.

The negative commodity supply shock results in domestic output falling, though this fall is very small (at its minimum it is approximately 0.5 per cent below the initial level). This compares to other studies, such as Dungey and Pagan (2000) and Jääskelä and Smith (2011), where domestic output increases in response to a terms of trade shock. ${ }^{5}$ However, Dungey and Pagan (2000) note that in an earlier version of their paper domestic output fell. This fall in domestic output reflects that the expansion of output in the resources sector in response to higher commodity prices, leads to factors

\footnotetext{
${ }^{5}$ Substituting the terms of trade for real commodity prices in the model results in the same effect on domestic output to a shock to the terms of trade variable.
} 
of production moving out of the non-resources sectors and into the resources sector, where higher prices are being paid for labour and capital. The fall in non resources sector output is not initially fully offset by the rise in resources sector output. While the higher exchange rate buffers the economy to the terms of trade shock, it does not do so fully. At the same time a higher exchange rate harms some areas of the economy, particularly the trade exposed manufacturing and services sectors.

Higher commodity prices leads to an immediate increase in the inflation rate, of approximately 0.4 per cent. This falls sharply in the second quarter after the shock in response to an appreciation of the real exchange rate and tighter monetary policy, as the interest rate rises in response to higher commodity prices and possibly greater demand for finance from the mining sector. However interest rates come off as commodity prices fall.

The exchange rate also rises contemporaneously with the rise in commodity prices, but comes off this peak due to lower Chinese steel production and foreign output. As Chinese steel production and foreign output trends up, commodity prices and the exchange rate remain at a new higher level over the impulse horizon. The higher real exchange rate appears to have a deflationary impact, with consumer prices remaining below the baseline level following the second year after the shock. This is consistent with Gruen and Dwyer (1995), who suggest that with a floating exchange rate, in some cases a positive terms of trade shock can be disinflationary.

\subsection{Shock to foreign output}

In response to the 0.5 per cent shock to foreign output, commodity prices rise during the first four quarters after the shock, peaking at 2.8 per cent above the baseline (Figure 6). Commodity prices fall from this peak, and remain below the baseline from the eighth quarter.

The shock to foreign output has a positive effect on the real value of Australian resource exports, partly due to higher commodity prices. Despite lower Chinese steel production resulting from higher input prices and possibly lower exports of Australian resources to China, higher demand from other Australian major trading partners may sustain the real value of resource exports above the baseline. In addition, the depreciation of the exchange rate after a year assists in increasing the quantity of resource exports.

Initially mining investment falls in response to the foreign output shock, possibly due to the fall in Chinese steel production. However, mining investment responds positively to the shock towards the end of the first year and this positive response 
is sustained out to the 30 month horizon, reflecting higher commodity prices. In the third year, mining investment falls below the baseline as commodity prices decline. The mining investment profile reflects the fact that it takes time for mining investment to ramp up and down again in response to changes in commodity prices. There is a positive effect on domestic output for the first year after the shock; however this drops off due to the tightening of monetary policy, with nominal interest rates rising in response to the pickup in domestic activity and commodity prices. Overall, the effect of the shock on domestic output is very small, ranging from 0.1 to -0.1 per cent. By the fifth year following the shock, domestic output is again above the baseline.

The rise in foreign output has an inflationary impact during the first three years following the shock due to higher commodity prices, foreign output and domestic output. However, as each of these variables fall below their initial levels, the shock has a deflationary impact. Despite an initial rise in the real exchange rate in response to higher commodity prices and foreign output, the exchange rate falls below its baseline level one year after the shock occurs and remains below the baseline, as a result of the falls in commodity prices and foreign output.

\subsection{Variance decompositions}

In Tables 1 and 2 the variance decomposition of the variables is presented. This shows the proportion of the variance of each variable that is attributable to shocks to each of the variables in the model. Results are reported for forecast horizons 1, 4, 12 and 24 quarters ahead. Table 1 presents the results for the external sector variables, while Table 2 presents the results for the domestic variables.

Focussing first on the external booming sector, the decompositions show that over the longer horizons most of the variance in each variable is explained by shocks in the external sector. For Chinese steel production at 24 quarters, 70 per cent of the variance is attributable to own production and world demand. For commodity prices, 75 percent of the variance is due to Chinese steel production (23 per cent), commodity prices (37 per cent) and world demand (15 per cent). World demand is dominated by shocks in itself ( 57 per cent) and commodity prices ( 16 per cent). There is some evidence that Australia has some market power in pricing in the commodity markets, as the remaining variance for the Chinese steel production variable and the commodity prices comes from Australian inflation, with 10 per cent and 13 per cent contributions to these two variables respectively.

For the value of resource exports and mining investment which are the sectors in Australia directly affected by the resources boom, it is mainly the external shocks 
which explain the variance of these variables. For the value of resource exports it is the booming sector in China (11 per cent), world demand (28 per cent) and own shocks (33 per cent) that are important at the longer horizon. It is not commodity prices or the exchange rate. For mining investment in the short run it is own shocks which dominate. However, over the longer time horizon Chinese steel production (20 per cent), commodity prices (14 per cent) and domestic inflation play a greater role (16 percent). It is interesting that shocks to Chinese steel production have a greater impact on mining investment than commodity prices over a longer time horizon. This may hold true as a large proportion of mining investment in Australia are joint ventures between mining companies and Chinese steel producers (Connolly and Orsmond, 2011).

For overall economic outcomes for Australia in terms of the GDP variable $\left(y d_{t}\right)$, over a longer time horizon, shocks to commodity prices are increasingly important, contributing 40 per cent to domestic output after 24 quarters which is slightly larger in magnitude than through their own shocks of 35 per cent after six years, which follows 59 per cent after three years.

\subsection{Robustness}

This section reports on the differences encountered when using alternative proxies for the mining investment variable and using two broader indicators in place of Chinese steel production.

Gross value added (GVA) for mining investment is considered as an alternative measure of mining investment. The consequences of this substitution for the impulse responses are relatively mild. The main difference six months after a commodity price shock is that the GVA of mining investment falls below baseline whereas mining investment itself remains positive. This is because of fewer resources being exported, resulting in falls in the resource export value and mining GVA. Lowe (2012) discusses the problems with the measurement of mining GVA, in particular that the current measurement does not take into account inputs that mining elicits from other sectors. Rayner and Bishop (2013) subsequently estimate this to be about 6.5 percent of GVA in 2011/2012. The difficulties with GVA suggest that our initial specification is preferred for this variable.

Broader measures of Chinese activity in the form of Chinese manufacturing and Chinese industrial production were also assessed in place of Chinese steel production. As might be expected, shocks to either of these proxies produced considerably smaller responses in commodity prices, with consequent flow through to all other areas of the model discussed in the previous section. When using Chinese industrial production 
as the output proxy, a shock to output dissipates much more quickly than in our model with steel production - that is shocks to steel production are longer lived. As a consequence the impacts on other variables in the model also have a considerably

shorter return to convergence. The robustness analysis suggests that the use of broader variables for Chinese activity do not capture the effects on the Australian economy via resources demand as effectively as steel production, supporting the specification reported in the previous section.

\section{Conclusion}

The boom in China has resulted in unprecedented demand for natural resources. This paper examines the effects of major industrialization in an emerging economy on a developed market whose structure is mostly based on abundant natural resources, using the example of Australia. Using a structural VAR framework, the questions addressed are: i) what are the effects of shocks from a rapidly growing emerging economy extracting resources from a developed natural resource rich economy on aggregate economic outcomes such as output growth, the interest rate, inflation and the exchange rate of the natural resource supplier; ii) how does the transmission of these shocks compare to general commodity price shocks once the China effects are abstracted from; iii) how does the transmission of these shocks compare to general foreign output shocks that are not dominated by resource demand; iv) how does the domestic resource export sector and the domestic mining sector react to the rapidly growing emerging economy under these circumstances; v) and how does mining investment and other economic activity in the natural resource economy feedback to affect the resource sector in the boom economy.

Overall, the effects of external booms in both the Chinese direct demand shock and the general commodity price shock are not positive for Australia over the longer time horizon. There is some evidence of Dutch disease in both of these shocks as resources transfer from the non-resource sector to the resources sector. The mechanisms of adjustment in response to the two shocks are slightly different. Shocks to Chinese demand as measured by Chinese steel production and shocks to commodity prices both result in an increase in commodity prices and mining investment for 40 years before their effects die out. The Chinese demand shock leads to an increase in output and inflation in the resource rich economy for a year and half, before monetary policy tightens, leading to lower output over the longer horizon. This effect remains until five years after the shock. 
The commodity price shock is reminiscent of a commodity supply shock, with foreign output falling and prices rising. The effect is contractionary for Australia, despite an increase in mining investment in response to the higher commodity prices. In response to the shock to commodity prices, real output in the resource supplying economy is below baseline levels one year after the shock. This fall reflects the movement of factors of production out of the non-resources sector of the economy and into the resources sector, as higher demand has driven up the price of labour and capital in the resources sector. As a result of lower output by the non-resources sector of the economy, real domestic output falls, with the rise in mining output failing to offset the fall in non-resources sector output. In response to the higher commodity prices, the floating exchange rate appreciates, acting as a shock absorber, and reducing the expansionary effects of the terms of trade rise on the overall economy.

The variance decompositions highlight some important results. First, there is some evidence that large resource suppliers have some market power in pricing in the commodity markets. The forecast error variance decomposition shows that after six years, 10 to 13 percent of the variance of the error of the Chinese steel production variable and the commodity price variable comes from Australian inflation, respectively. For the value of resource exports and mining investment which are the sectors in Australia directly affected by the resources boom, it is mainly the external shocks which explain the variance of the error term. For resource exports it is the booming sector in China, world demand and own shocks that are important at the longer horizon. It is not commodity prices or the exchange rate. For mining investment in the short run it is own shocks which dominate. However, over the longer time horizon Chinese steel production, commodity prices and domestic inflation play a greater role. Chinese steel production has a greater impact on mining investment than commodity prices over a longer time horizon.

\section{References}

[1] ABARES, June quarter 2011. Australian commodities.

Amisano, G., Giannini, C., 1997. Topics in structural VAR econometrics, 2nd ed. Springer Berlin Heidelberg.

Batellino, R., 2010. Mining booms and the Australian economy. Address to The

Sydney Institute, Sydney, 23 February 2010. Available online at: http://www.rba.gov.au/speeches/2010/ dg-230210.html. 
Beine, M., Bos, C., Coulombe, S., 2012. Does the canadian economy suffer from Dutch Disease? Resource and Energy Economics 34, 468-492.

Berkelmans, L., 2005. Credit and monetary policy: An Australian SVAR. Research Discussion Paper 2005-06, Reserve Bank of Australia.

Brischetto, A., Voss, G., 1999. A structural vector autoregression model of monetary policy in Australia. Research Discussion Paper 1999-11, Reserve Bank of Australia.

Clements, K.W., Fry, R.A., 2008. Commodity currencies and currency commodities. Resources Policy 10, 1-19.

Connolly, E., Orsmond, D., 2011. The mining industry: from bust to boom. Research Discussion Paper 2011-8, Reserve Bank of Australia.

Cordon, W.M., 1984. Booming sector and Dutch disease economics: Survey and consolidation. Oxford Economic Papers 36(3), 359-380.

Cordon, W.M., Neary, J.P., 1982. Booming sector and de-industrialisation in a small open economy. Economic Journal 92(386), 825-848.

Dornbusch, R., 1987. Exchange rate economics. Economic Journal 97, 1-18.

Dungey, M., Fry, R., 2009. The identification of fiscal and monetary policy in a structural VAR. Economic Modelling 26(6), 1147-1160.

Dungey, M., Pagan, A., 2000. A structural VAR model of the Australian economy. The Economic Record 76(235), 321-342.

Dungey, M., Pagan, A., 2009. Extending a SVAR model of the Australian economy. Economic Record 85(268), 1-20.

Feng, L., 1994. China's steel industry: its rapid expansion and influence on the international steel industry. Resources Policy 20, 219-234.

Fry, R., Pagan, A., 2011. Sign restrictions in structural vector autoregressions: A critical review. Journal of Economic Literature 49(4), 938-960.

Gruen, D., Dwyer, J., 1995. Are terms of trade rises inflationary? Research Discussion Paper 9508, Reserve Bank of Australia.

Gylfason, T., Herbertsson, T.T., Zoega, G., 1999. A mixed blessing: Natural resources and economic growth. Macroeconomic Dynamics 3, 204-255.

Hamilton, J., 1994. Time series analysis. Princeton University Press, Princeton.

Humphreys, D., 2010. The great metals boom: A retrospective. Resources Policy $35,1-13$.

Jääskelä, J., Smith, P., 2011. Terms of trade shocks: What are they and what do they do? Research Discussion Paper 2011-05, Reserve Bank of Australia.

Lawson, J., Rees, D., 2008. A sectoral model of the Australian economy. Research 
Discussion Paper 2008-01, Reserve Bank of Australia.

Lowe, P., 2012. Developments in the mining and non-mining economies. Address to the ADC Future Summit, Melbourne - 14 May 2012.,

http://www.rba.gov.au/speeches/2012/sp-dg-140512.html (accessed June 12, 2013).

Liu, P., 2008. The role of international shocks in Australia's business cycle. Research Discussion Paper 2008-08, Reserve Bank of Australia.

Mercer, P., 2011. Can Australia's new mining tax achieve its objective? BBC News (British Broadcasting Corporation). 23 November 2011.

Mudd, G., 2010. The environmental sustainability of mining in Australia: Key mega-trends and looming constraints. Resources Policy 35, 29-115.

Plumb, M., Kent, C., Bishop, J., 2013. Implications for the Australian economy of strong growth in Asia. Research Discussion Paper 2013-03, Reserve Bank of Australia.

Roache, S., 2012. China's impact on world commodity markets, IMF Working Paper 12/115.

Rayner, V., Bishop, J., 2013. Industry dimensions of the resource boom: An InputOutput analysis. Research Discussion Paper 2013-02, Reserve Bank of Australia, Sydney.

Reserve Bank of Australia, 2009. Updating the RBA's index of commodity prices. Reserve Bank Bulletin, October 2009., Available online at:

http://www.rba.gov.au/publications/bulletin/2009/oct/2.html (accessed June 12, 2013).

Roberts, I., Rush, A., 2010. Sources of Chinese demand for resource commodities. Research Discussion Paper 2010-8, Reserve Bank of Australia.

Sachs, J.D., Warner, A.M., 1999. The big push, natural resource booms and growth. Journal of Development Economics 59(1), 43-76.

Sims, C., 1992. Interpreting the macroeconomic time series facts: The effects of monetary policy. European Economic Review 36(5), 975-1000.

Stijins, J., 2005. Natural resource abundance and economic growth. Resources Policy 30, 107-130.

Sjaastad, L.A., 1998a. On exchange rates, nominal and real. Journal of International Money and Finance 17, 407-439.

Sjaastad, L.A., 1998b. Why PPP real exchange rates mislead. Journal of Applied Economics 1, 179-207.

Tcha, M., Wright, D., 1999. Determinants of China's import demand for Australia's iron ore. Resources Policy 25, 143-149. 
Truman, E.M.,2011. Sovereign wealth funds: threat or salvation? Peterson Institute.

Vespignani, J., 2013. The industrial impact of monetary shocks during the inflationtargeting era in Australia. Australian Economic History Review 53, 47-71.

Zhang, Y., Zheng, C., 2008. The implications of China's rapid growth on demand for energy and mining products imported from Australia. Economic Papers 27, 95-106. 
Table 1: Forecast Error Variance Decomposition of the External Variables in \%.

\begin{tabular}{|c|c|c|c|c|c|c|c|c|c|c|c|}
\hline var. & shock & 1 & 4 & 12 & 24 & var. & shock & 1 & 4 & 12 & 24 \\
\hline \multirow[t]{9}{*}{$\operatorname{csp}_{t}$} & $c s p_{t}$ & 100.00 & 57.87 & 36.49 & 26.81 & $y w_{t}$ & $c s p_{t}$ & 0.03 & 3.95 & 3.78 & 3.94 \\
\hline & $p c_{t}$ & 0.00 & 7.76 & 2.47 & 2.90 & & $p c_{t}$ & 0.46 & 8.14 & 16.42 & 16.00 \\
\hline & $y w_{t}$ & 0.00 & 11.69 & 36.82 & 42.53 & & $y w_{t}$ & 99.51 & 80.61 & 59.07 & 57.18 \\
\hline & resx $x_{t}$ & 0.00 & 5.81 & 3.82 & 3.73 & & resx $_{t}$ & 0.00 & 1.39 & 2.30 & 2.05 \\
\hline & $\operatorname{mininv}_{t}$ & 0.00 & 1.64 & 0.92 & 1.90 & & $\operatorname{mininv}_{t}$ & 0.00 & 0.48 & 0.79 & 1.42 \\
\hline & $y d_{t}$ & 0.00 & 0.19 & 0.28 & 6.79 & & $y d_{t}$ & 0.00 & 0.04 & 1.97 & 3.98 \\
\hline & $p d_{t}$ & 0.00 & 14.70 & 15.08 & 10.17 & & $p d_{t}$ & 0.00 & 3.15 & 6.80 & 6.30 \\
\hline & $r d_{t}$ & 0.00 & 0.04 & 2.68 & 1.89 & & $r d_{t}$ & 0.00 & 2.06 & 2.55 & 3.19 \\
\hline & $q_{t}$ & 0.00 & 0.29 & 1.45 & 3.29 & & $q_{t}$ & 0.00 & 0.18 & 6.31 & 5.93 \\
\hline \multirow[t]{9}{*}{$p c_{t}$} & $c s p_{t}$ & 5.26 & 22.92 & 27.13 & 22.51 & resx $_{t}$ & $c s p_{t}$ & 0.30 & 7.74 & 11.32 & 10.56 \\
\hline & $p c_{t}$ & 94.74 & 53.11 & 37.41 & 36.57 & & $p c_{t}$ & 0.93 & 2.02 & 4.54 & 4.71 \\
\hline & $y w_{t}$ & 0.00 & 11.75 & 9.73 & 15.48 & & $y w_{t}$ & 1.49 & 7.18 & 23.43 & 28.30 \\
\hline & resx $_{t}$ & 0.00 & 1.53 & 4.26 & 2.84 & & resx $_{t}$ & 97.28 & 66.03 & 40.54 & 32.70 \\
\hline & $\operatorname{mininv}_{t}$ & 0.00 & 0.20 & 0.49 & 1.16 & & $\operatorname{mininv}_{t}$ & 0.00 & 0.98 & 1.15 & 2.62 \\
\hline & $y d_{t}$ & 0.00 & 0.20 & 0.13 & 0.45 & & $y d_{t}$ & 0.00 & 5.27 & 8.36 & 10.66 \\
\hline & $p d_{t}$ & 0.00 & 5.66 & 16.86 & 12.80 & & $p d_{t}$ & 0.00 & 6.47 & 6.70 & 5.67 \\
\hline & $r d_{t}$ & 0.00 & 1.76 & 0.96 & 0.71 & & $r d_{t}$ & 0.00 & 1.08 & 1.46 & 1.22 \\
\hline & $q_{t}$ & 0.00 & 2.87 & 3.03 & 7.48 & & $q_{t}$ & 0.00 & 3.23 & 2.51 & 3.57 \\
\hline
\end{tabular}


Table 2: Forecast Error Variance Decomposition of the Domestic Variables in \%.

\begin{tabular}{|c|c|c|c|c|c|c|c|c|c|c|c|}
\hline var. & shock & 1 & 4 & 12 & 24 & var. & shock & 1 & 4 & 12 & 24 \\
\hline \multirow[t]{9}{*}{$\operatorname{mininv}_{t}$} & $c s p_{t}$ & 0.23 & 3.56 & 16.77 & 20.25 & \multirow[t]{9}{*}{$p d_{t}$} & $c s p_{t}$ & 1.21 & 14.86 & 11.75 & 9.84 \\
\hline & $p c_{t}$ & 2.57 & 8.98 & 7.33 & 13.79 & & $p c_{t}$ & 9.57 & 3.03 & 2.19 & 5.71 \\
\hline & $y w_{t}$ & 2.86 & 3.78 & 10.22 & 15.85 & & $y w_{t}$ & 0.01 & 16.66 & 13.55 & 18.02 \\
\hline & resx. & 0.10 & 0.86 & 1.06 & 1.20 & & resx $_{t}$ & 0.04 & 4.48 & 11.01 & 9.12 \\
\hline & $\operatorname{mininv}_{t}$ & 94.24 & 78.21 & 39.61 & 20.49 & & $\operatorname{mininv}_{t}$ & 0.25 & 0.12 & 1.53 & 3.05 \\
\hline & $y d_{t}$ & 0.00 & 0.48 & 4.45 & 4.88 & & $y d_{t}$ & 3.67 & 8.88 & 31.23 & 29.37 \\
\hline & $p d_{t}$ & 0.00 & 3.95 & 18.40 & 16.38 & & $p d_{t}$ & 6.48 & 4.07 & 4.96 & 4.33 \\
\hline & $r d_{t}$ & 0.00 & 0.13 & 2.04 & 3.23 & & $r d_{t}$ & 78.77 & 45.48 & 20.44 & 17.58 \\
\hline & $q_{t}$ & 0.00 & 0.04 & 0.12 & 3.93 & & $q_{t}$ & 0.00 & 2.43 & 3.34 & 2.97 \\
\hline \multirow[t]{9}{*}{$y d_{t}$} & $c s p_{t}$ & 3.31 & 2.11 & 1.31 & 4.23 & \multirow[t]{9}{*}{$q_{t}$} & $c s p_{t}$ & 3.96 & 15.52 & 19.78 & 20.46 \\
\hline & $p c_{t}$ & 1.29 & 5.39 & 18.17 & 40.48 & & $p c_{t}$ & 9.34 & 3.74 & 13.74 & 16.88 \\
\hline & $y w_{t}$ & 0.94 & 0.43 & 1.47 & 1.12 & & $y w_{t}$ & 5.83 & 8.88 & 7.53 & 13.14 \\
\hline & resxt & 1.32 & 6.40 & 4.36 & 2.76 & & resx $x_{t}$ & 0.10 & 4.85 & 4.71 & 4.31 \\
\hline & $\operatorname{mininv}_{t}$ & 0.00 & 3.15 & 5.58 & 3.61 & & $\operatorname{mininv}_{t}$ & 1.04 & 4.14 & 7.15 & 6.41 \\
\hline & $y d_{t}$ & 93.14 & 81.08 & 58.78 & 34.96 & & $y d_{t}$ & 0.28 & 1.49 & 3.49 & 4.02 \\
\hline & $p d_{t}$ & 0.00 & 0.04 & 0.15 & 1.76 & & $p d_{t}$ & 0.88 & 5.09 & 10.83 & 11.55 \\
\hline & $r d_{t}$ & 0.00 & 0.92 & 4.36 & 2.89 & & $r d_{t}$ & 5.41 & 2.39 & 2.33 & 1.51 \\
\hline & $q_{t}$ & 0.00 & 0.50 & 5.82 & 8.19 & & $q_{t}$ & 73.17 & 53.90 & 30.44 & 21.73 \\
\hline \multirow[t]{9}{*}{$p d_{t}$} & $c s p_{t}$ & 0.27 & 1.37 & 4.77 & 4.40 & & & & & & \\
\hline & $p c_{t}$ & 4.12 & 4.59 & 3.37 & 4.41 & & & & & & \\
\hline & $y w_{t}$ & 0.00 & 0.26 & 2.45 & 8.46 & & & & & & \\
\hline & resx $_{t}$ & 0.00 & 3.60 & 8.28 & 7.31 & & & & & & \\
\hline & $\operatorname{mininv}_{t}$ & 0.00 & 1.66 & 1.86 & 2.96 & & & & & & \\
\hline & $y d_{t}$ & 0.02 & 6.64 & 25.08 & 24.06 & & & & & & \\
\hline & $p d_{t}$ & 95.59 & 77.07 & 46.77 & 40.55 & & & & & & \\
\hline & $r d_{t}$ & 0.00 & 3.90 & 4.70 & 5.17 & & & & & & \\
\hline & $q_{t}$ & 0.00 & 0.91 & 2.73 & 2.68 & & & & & & \\
\hline
\end{tabular}




\begin{tabular}{|c|c|c|}
\hline variable & code & source \\
\hline China steel product & $\operatorname{csp}$ & s.a. (Datastream code: CHVALSTLH) \\
\hline Commodity prices & $p c$ & $\begin{array}{l}\text { Index of commodity prices in US dollars } \\
\text { (RBA, Statistical Table G5) } \\
\text { deflated by the US CPI for All Urban Consumers: } \\
\text { All Items (Bureau of Labor Statistics) }\end{array}$ \\
\hline Foreign output & $y w$ & $\begin{array}{l}\text { s.a. export-weighted real GDP of Australia's major } \\
\text { trading partners (RBA) }\end{array}$ \\
\hline Aust resource exports & resx & $\begin{array}{l}\text { sum of the value of exports of Metal ores and minerals, } \\
\text { Coal, coke and briquettes, Other mineral fuels, Metals } \\
\text { (excluding non-monetary gold) } \\
\text { and Non-monetary gold, chain volume measure, } \\
2009-10 \text { prices, s.a. (ABS Cat. No. } 5302.0 \text { ) }\end{array}$ \\
\hline Mining investment & $\operatorname{mininv}$ & $\begin{array}{l}\text { Mining Private New Capital Expenditure, chain volume } \\
\text { measure, 2009-10 prices, s.a. (ABS Cat. No. } 5625.0 \text { ) }\end{array}$ \\
\hline Domestic output & $y d$ & $\begin{array}{l}\text { s.a. chain volume measure of non-farm gross domestic } \\
\text { product (ABS Cat No 5206.0) }\end{array}$ \\
\hline Inflation & $p d$ & $\begin{array}{l}\text { s.a. trimmed-mean consumer price index, } 1989 / 90=100 \text {, } \\
\text { excluding interest charges, adjusted for the tax changes of } \\
\text { 1999-2000 (RBA) }\end{array}$ \\
\hline Cash rate & $r d$ & $\begin{array}{l}\text { quarterly average of the target cash rate } \\
\text { (RBA Statistical Table F1) }\end{array}$ \\
\hline Exchange rate & & real trade-weighted index (RBA Statistical Table F15) \\
\hline $\begin{array}{c}\text { China manfact } \\
\text { exports }\end{array}$ & $c m x$ & $\begin{array}{l}\text { manufacturing exports in US dollars } \\
\text { (Datastream code: CHEXMANUA) deflated by the } \\
\text { US CPI for All Urban Consumers: All Items } \\
\text { (Bureau of Labor Statistics) }\end{array}$ \\
\hline China Industrial Product & cip & (Datastream code: CHIPTOT.H) \\
\hline Mining gross value added & mingva & $\begin{array}{l}\text { Mining excluding exploration and mining support services, } \\
\text { chain volume measure, } 2009-10 \text { prices, } \\
\text { seasonally adjusted (ABS Cat. No. } 5206.0 \text { ) }\end{array}$ \\
\hline
\end{tabular}


Figure 1: Australia's Terms of Trade

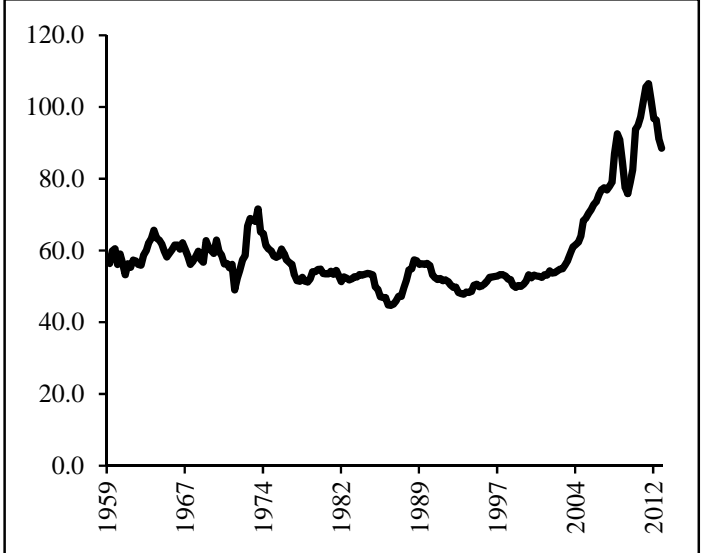

Index (2010/11 = 100)

Source: ABS Cat. No. 5602.0
Figure 2: RBA Index of Commodity Prices

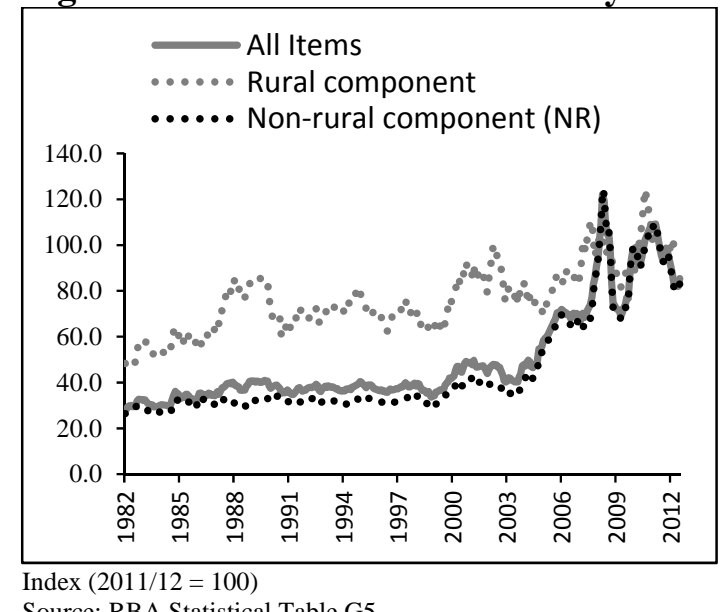

Source: RBA Statistical Table G5

Figure 3: Mining investment as a share of GDP (per cent, current prices, sa)

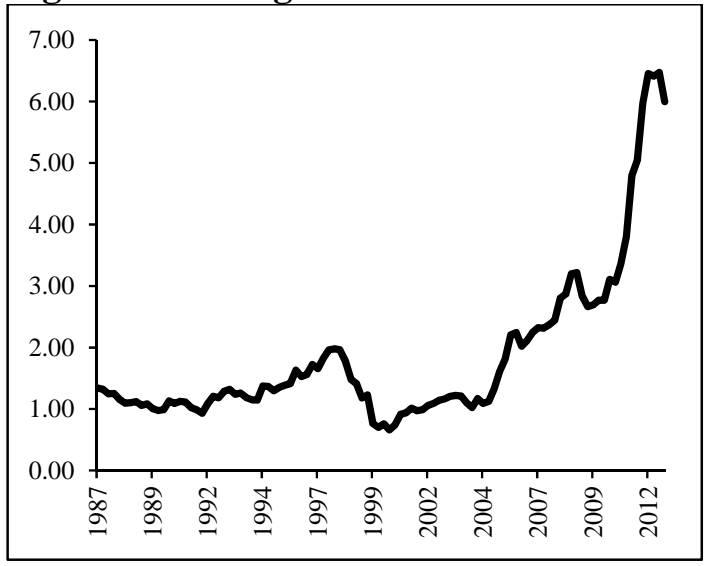

Source: ABS Cat. No. 5206.0 and 5625.0 
Figure 4: Impulse responses to shock to Chinese steel production
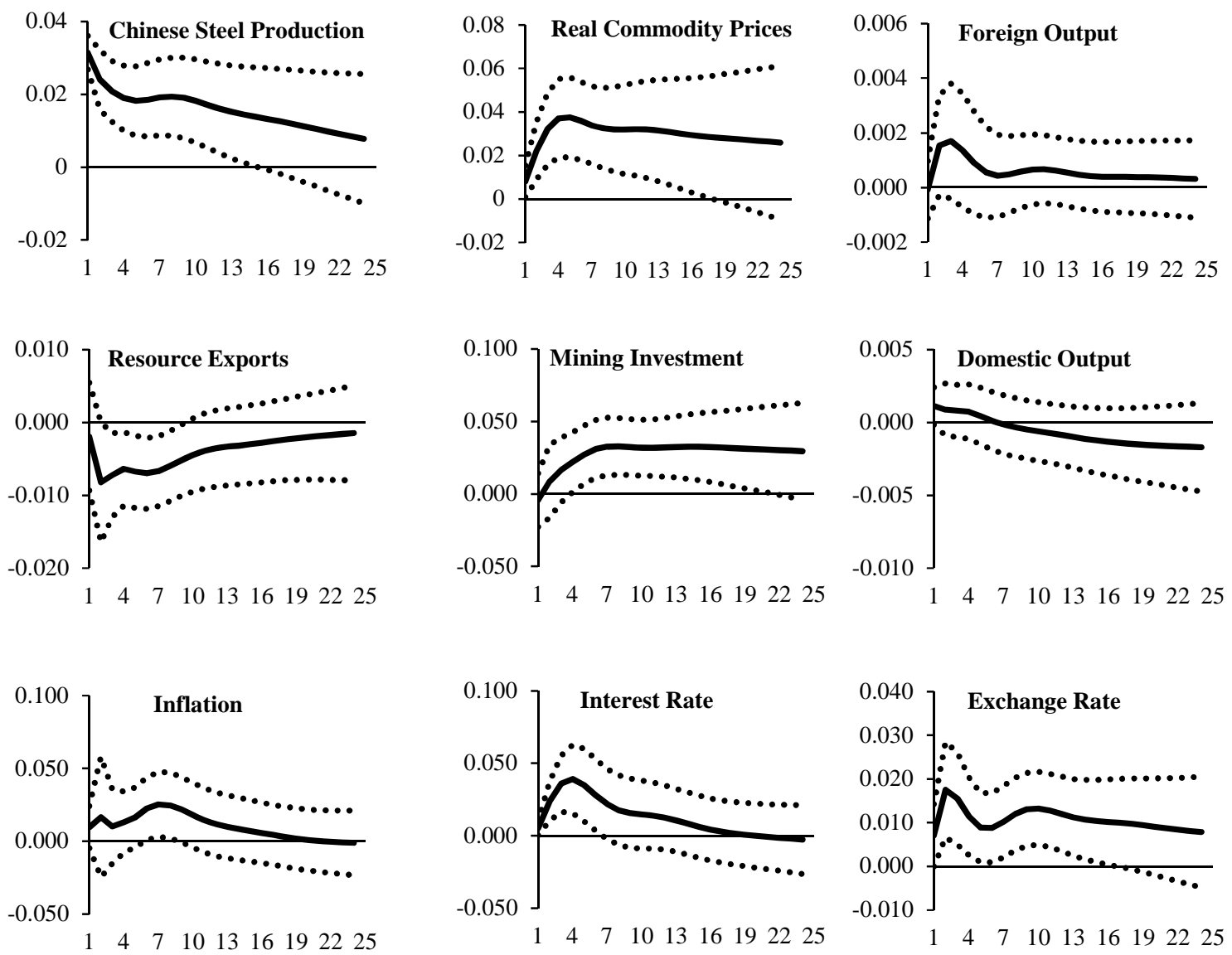
Figure 5: Impulse responses to shock to commodity prices
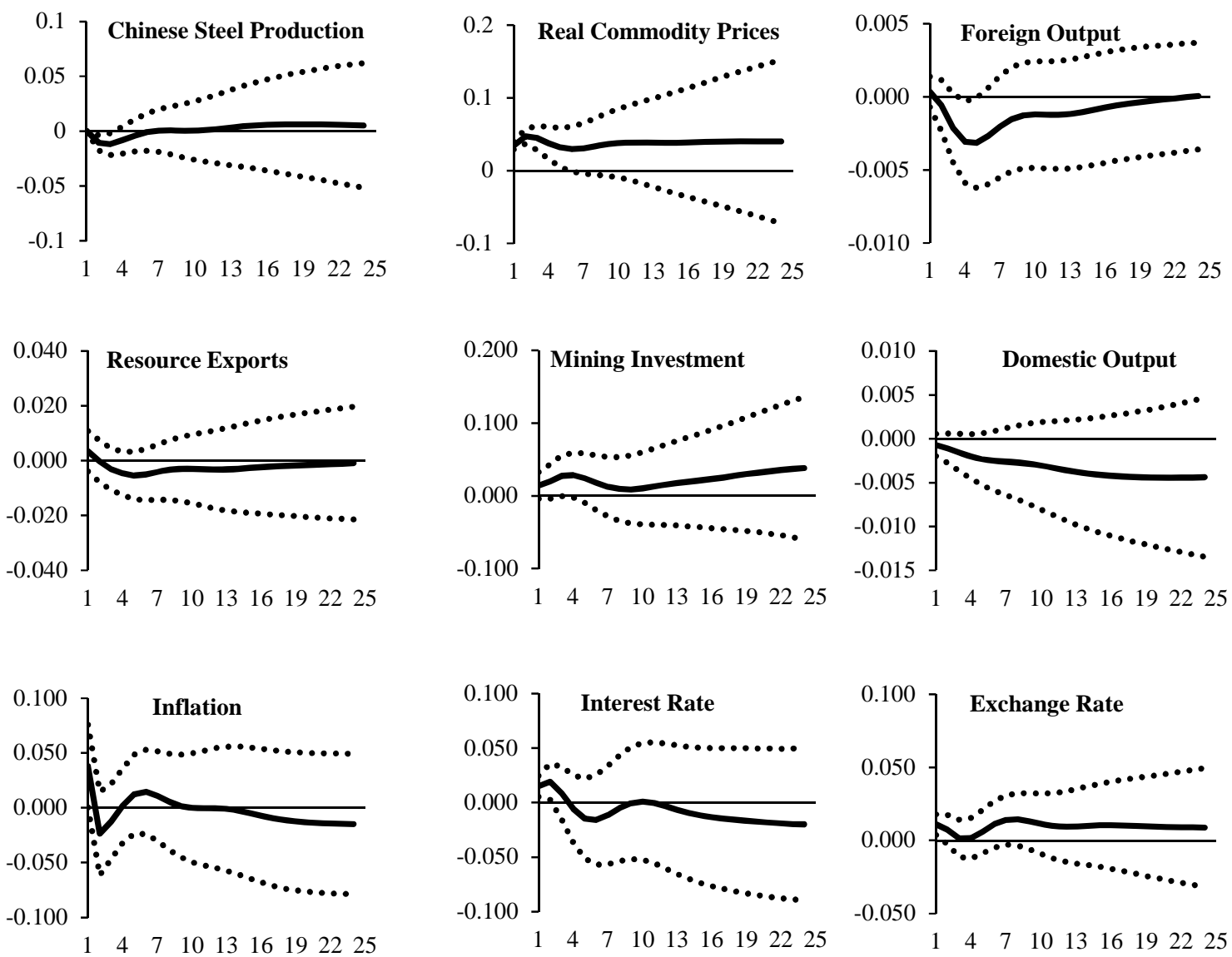
Figure 6: Impulse responses to shock to foreign output
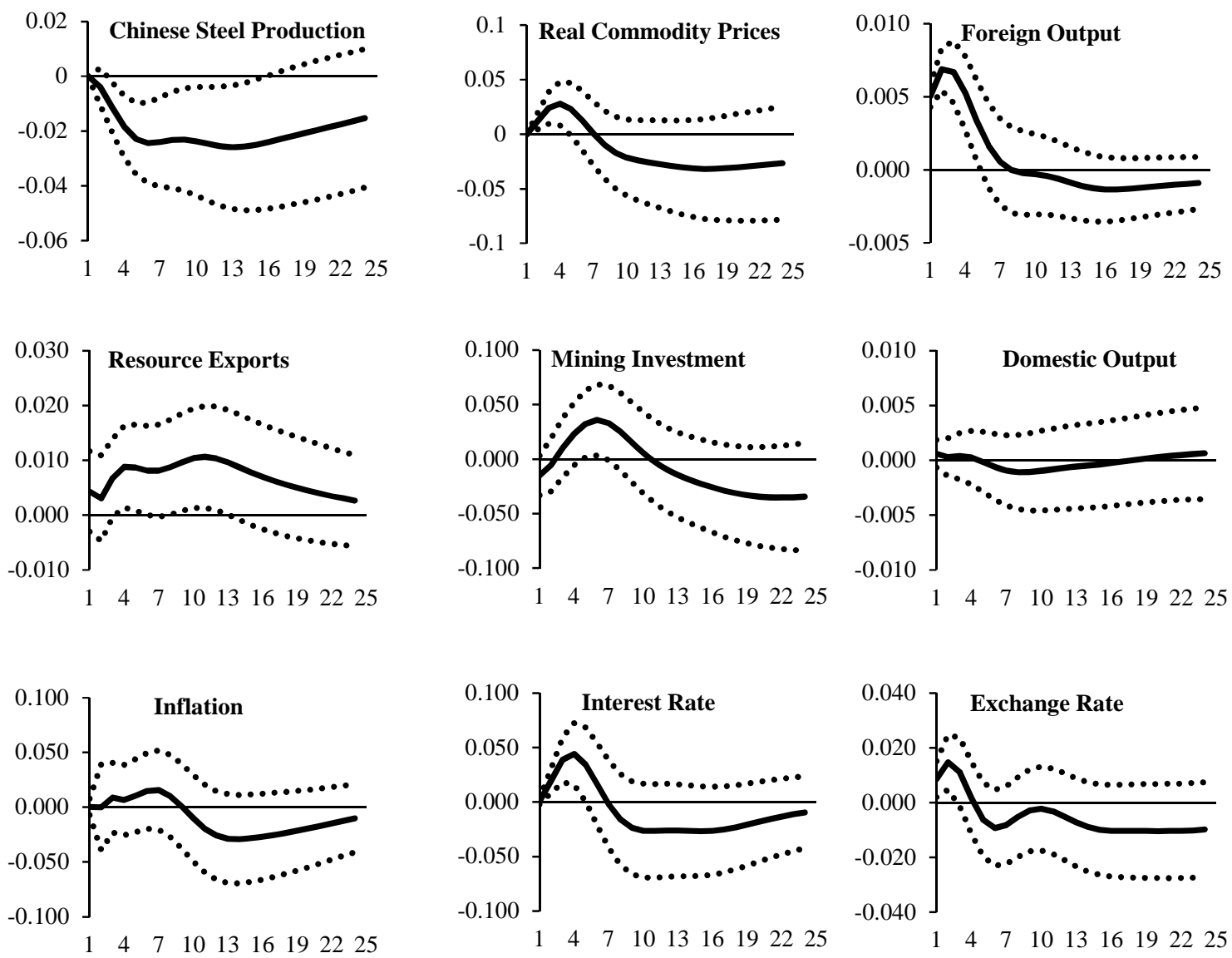


\section{School of Economics and Finance Discussion Papers}

2013-07 Chinese Resource Demand and the Natural Resource Supplier Mardi Dungy, Renée Fry-McKibbin and Verity Linehan

2013-06 Not All International Monetary Shocks are Alike for the Japanese Economy, Joaquin L Vespignani and Ronald A Ratti

On Bootstrap Validity for Specification Tests with Weak Instruments, Firmin Doko Tchatoka

2013-04 Chinese Monetary Expansion and the US Economy, Joaquin L Vespignani and Ronald A Ratti International Monetary Transmission to the Euro Area: Evidence from the US, Japan and China,

Joaquin L Vespignani and Ronald A Ratti

The impact of jumps and thin trading on realized hedge ratios? Mardi Dungey, Olan T. Henry, Lyudmyla Hvozdyk Why crude oil prices are high when global activity is weak?, Ronald A Rattia and Joaquin L Vespignani Crude Oil Prices and Liquidity, the BRIC and G3 Countries, Ronald A Ratti and Joaquin L Vespignani Crude Oil Prices: China’s Influence Over 1996-2011, Ronald A Ratti and Joaquin L Vespignani Exchange Rate Risk Exposure and the Value of European Firms, Fabio Parlapiano and Vitali Alexeev Ranking Systemically Important Financial Institutions, Mardi Dungey, Matteo Luciani and David Veredas

Identification-Robust Inference for Endogeneity Parameters in Linear Structural Models, Firmin Doko Tchatoka and Jean-Marie Dufour Specification Tests with Weak and Invalid Instruments, Firmin Doko Tchatoka Liquidity and Crude Oil Prices: China’s Influence Over 1996-2011, Ronald A. Rattia and Joaquin L. Vespignani

2012-03 Endogenous Crisis Dating and Contagion Using Smooth Transition Structural GARCH, Mardi Dungey, George Milunovich, Susan Thorp and Minxian Yang

2012-02 Testing for Partial Exogeneity with Weak Identification, Firmin Doko Tchatoka

2012-01 On the Correspondence Between Data Revision and Trend-Cycle Decomposition, Mardi Dungey, Jan PAM Jacobs and Jian Tian

Systematic and Liquidity Risk in Subprime-Mortgage Backed Securities, Mardi Dungey, Gerald P. Dwyer and Thomas Flavin

2011-05 A SVECM Model of the UK Economy and The Term Premium, Mardi Dungey and M. Tugrul Vehbi

2011-04 Do Contact Matter in the Process of Getting a Job in Cameroon? Firmin Doko Tchatoka and Urbain Thierry Yogo

2011-03 Subset Hypotheses Testing and Instrument Exclusion in the Linear IV Regression, Firmin Doko Tchatoka

2011-02 First home Buyers’ Support Schemes in Australia - Results Spreadsheet, Mardi Dungey, Graeme Wells and Sam Thompson

2011-01 First home Buyers’ Support Schemes in Australia, Mardi Dungey, Graeme Wells and Sam Thompson

Copies of the above mentioned papers and a list of previous years' papers are available from our home site at http://www.utas.edu.au/economics-finance/research/ 